\title{
Intensive Neuromotor Therapy improves motor skills of children with Cornelia de Lange Syndrome: case report
}

\author{
Terapia Intensiva Neuromotora melhora as habilidades motoras \\ da criança com Síndrome de Cornélia de Lange: relato de caso
}

\section{El cuidado intensivo neuromotor mejora las habilidades motoras de los niños con síndrome de Cornelia de Lange: reporte de caso}

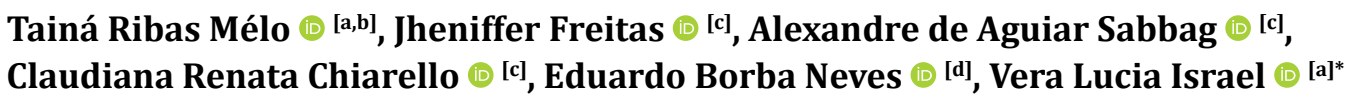

[a] Universidade Federal do Paraná (UFPR), Curitiba, PR, Brazil

${ }^{[b]}$ Instituto Brasileiro de Terapias e Ensino (Ibrate), Curitiba, PR, Brazil

${ }^{[c]}$ Centro de Pesquisa Vitória, Curitiba, PR, Brazil

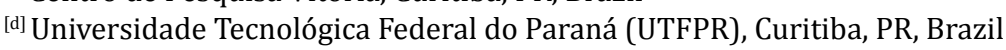

\begin{abstract}
Introduction: The Cornelia de Lange Syndrome $(\mathrm{CdLS})$ is a rare genetic syndrome. Children with CdLS usually require physical therapy, however the efficacy of physical therapy intervention in this population is lacking in the research literature. Objective: The aim of this study was to report the effect of Intensive Neuromotor Therapy (INMT) on gross motor function and participation of a child with CdLS using the International Classification of Functioning, Disabilities and Health (ICF) model. Method: A Brazilian child with CdLS was followed for over seven months while undergoing three modules of INMT. Results: The child demonstrated an evolution of gross motor function with gains of $11.28 \%$ in the first module, $9.22 \%$ in the second module, and $10.29 \%$ in the third module of INMT. Conclusion: INMT resulted in improvements in
\end{abstract}

\footnotetext{
* TRM: PhD, e-mail: ribasmelo@gmail.com JF: BS, e-mail: jhenifferfreitas@hotmail.com AAS: BS, e-mail: sabugo_1984@hotmail.com CRC: BS, e-mail: claudianachiarello@gmail.com EBN: PhD, e-mail: neveseb@gmail.com VLI: PhD, e-mal: veral.israel@gmail.com
} 
gross motor function and participation during daily activities in a child with CDLS. Further studies of larger cohorts are needed to investigate the efficacy of INMT in children with CdLS.

Keywords: Cornelia de Lange Syndrome. Physical Therapy. Motor Skills.

\section{Resumo}

Introdução: A síndrome de Cornelia de Lange (SCL) é uma síndrome genética rara. Crianças com SCL geralmente necessitam de fisioterapia, porém a eficácia da intervenção fisioterapêutica nessa população é escassa na literatura científica. Objetivo: $O$ objetivo deste estudo foi relatar o efeito da Terapia Neuromotora Intensiva (TNMI) sobre a função motora grossa e participação de uma criança com SCL usando o modelo de Classificação Internacional de Funcionalidades, Incapacidades e Saúde (CIF). Método: Uma criança brasileira com SCL foi acompanhada durante sete meses, enquanto submetida a três módulos de TNMI. Resultados: A criança demonstrou uma evolução da função motora grossa com ganhos de 11,28\% no primeiro módulo, 9,22\% no segundo módulo e 10,29\% no terceiro módulo do TNMI. Conclusão: a TNMI resultou em melhorias na função motora grossa e participação durante as atividades diárias em uma criança com SCL. São necessários mais estudos de coortes para investigar a eficácia do TNMI em crianças com SCL.

Palavras-chave: Síndrome de Cornélia de Lange. Fisioterapia. Habilidade Motora.

\section{Resumen}

Introducción: El síndrome de Cornelia de Lange (SCL) es un síndrome genético raro. Los niños con SCL por lo general requieren fisioterapia, sin embargo, es escasa en la literatura científica la eficacia de esta intervención en este público. Objetivo: Informar el efecto de la terapia neuromotora intensiva (TNMI) en la función motora gruesa y la participación de un niño con SCL mediante el modelo de Clasificación Internacional de Funcionamiento, Discapacidades y Salud (CIF). Método: Se puso en seguimiento a un niño brasileño con SCL durante siete meses mientras se sometía a tres módulos de TNMI. Resultados: El niño demostró una evolución de la función motora gruesa con ganancias de un 11,28\% en el primer módulo, de un 9,22\% en el segundo y de un 10,29\% en el tercer módulo de TNMI. Conclusión: La TNMI presentó mejoras en la función motora gruesa y en la participación durante las actividades diarias en un niño con SCL. Se necesitan futuras investigaciones adicionales de cohortes para investigar la eficacia de TNMI en niños con SCL.

Palavras clave: Síndrome de Cornelia de Lange. Fisioterapia. Habilidades Motoras.

\section{Introduction}

The Cornelia de Lange Syndrome (CdLS) was first described in 1916. The first publication was dated from 1933, in Holland [1]. CdLS is considered as a rare genetic development syndrome [2], affecting 0.5 to 0.6 for each 100.000 born [1], without distinction of race. This syndrome is more prevalent in female with a proportion of 3:1 [3].

The most accepted etiology is the autosomal recessive genetic origin through the gene mutation. Regarding to genetic alterations, there are 5 genes commonly identified as causative (NIPBL, RAD21, SMC3, a hemizyous pathogenic variant in HDAC8 or SMC1A), with NIPBL (Nipped B gene Like) being the most common $[4,5]$, even some studies showing normal karyotype [6], which leads to the possibility of several phenotypic manifestations.

The CdLS may cause variable phenotypic such as delay on growth and neuromotor development, distinctive facial features (microbrachycephaly), low hair implantation, wider and joined eyebrows, hypertrichosis, small nose, thin lips and micrognathia. Other alterations less frequent are malformation of 
hands (syndactyly), agenesis, cardiopathies, skeletal, visual and digestive alterations, which demonstrate the complexity of the case $[2,3]$.

Most of CdLS children present intellectual impairments [3] from moderate to severe [7]. Some of them also have behavioral alteration "including aggressive, self-injurious, mood disturbance, and autistic-like traits" [5].

The diagnosis is made through these phenotypic features associated with growth and motor skills development analysis. In CdLS is also expected impairments in the voluntary movement [8]. In the neurological rehabilitation area, to identify these aspects is not easy. Children with CdLS were recommended to have a multidisciplinary intervention $[9,10]$. Two studies regarding CdLS $[1,6]$ describe clinical and genetic aspects, with no report of physical therapy for these cases.

The International Classification of Functioning, Disabilities and Health (ICF) $[11,12]$ recommend the Gross Motor Function Measure (GMFM) for evaluating motor function and daily activities [13] in children with neuromotor disorders [5].

For children with neurological disorders, physical therapy with intensive protocols can be an alternative to increase results [14]. In this sense, the Intensive Neuromotor Therapy (INMT) $[15,16]$ is a modular training composed of 2-3h/day of physical activities, 5 times a week, during 4 weeks, with rest or maintenance periods between modules. The INMT can use orthotic garments or suit wear which offers movement resistance, and the therapy can be done in an Abiliy Unit of Exercise (AUE) using bungee cords to provide sensory stimulation, movement through resistance, standing posture and balance strategies [17] during the therapy. Most of the previous studies were performed with cerebral palsy children [14], but positive effects in gross motor skills were also showed in Down syndrome [18] and in spinal amyotrophy [19].

Thus, the aim of this study was to report the effect of Intensive Neuromotor Therapy on gross motor function, and participation in daily activities of a child with Cornelia de Lange Syndrome using the International Classification of Functioning, Disabilities and Health model.

\section{Methods}

This study can be characterized as a case report, which used retrospective analyses of records from a child with CdLS. This investigation was approved by the Research Ethics Committee from the Brazilian Institute of Therapies and Teaching (Ibrate) registered under number 1.429.717, clinical registration RBR2st594. The INMT was performed in a Center of Rehabilitation, in Curitiba, Paraná, Brazil, with the parents' consent.

\section{History}

The history was collected in the first evaluation, and the parents responded an informal interview with information about health, daily and education activities.

The mother at 35 years of age presented: hypertension, obesity and risk pregnancy. The child was born on $03 / 11 / 2013$ with 30 weeks gestational age, showing fetal distress. At birth, weight was $1,060 \mathrm{~kg}$ and $34 \mathrm{~cm}$ of height. The child remained in the intensive care unit (ICU) for nearly five months. The child had a CdLS diagnosis considering some signals: microcephaly, malformations of the upper limbs, medial axial slit in the hand associated with syndactyly, delay of motor skills development. He feeds through gastrostomy (fundoplication performed at 3 months) and he had undergone surgery for testicular hernia repair (left) and excision of a sebaceous cyst. Because of it, he started to use the following drugs: phenobarbital, amlodipine, enalapril, furosemide, protovita plus vitamin D and cephalexin .

In a chest X-ray, he had report as "Rising Heart", later confirmed as cardiac malformation (Ebstein's anomaly) by echocardiography. The child presents normal axial and appendicular muscle tone, and facial hypertonia. The fusion of the posterior arch of T11, L5 e S1 and shortening of the vertebral body of T11 was observed in an anteroposterior spine X-ray. At the beginning of INMT, he was 2 years-old, $12.0 \mathrm{~kg}, 79 \mathrm{~cm}$.

\section{Evaluation}

The gross motor function was assessed by the same therapist using the Gross Motor Function Measure (GMFM-88). The GMFM-88 quantifies motor aspects through 88 items scored from 0 to 3 [13] and consists in a motor function evaluation by ICF domains [11, 12]. The physiotherapist who evaluated the child was the same therapist who did the interventions, and has experience. The GMFM-88 was applied in a single day, inside a large and comfortable room with the floor 
covered by acetate-vinyl ethylene (EVA). The child wore comfortable clothes that allowed full mobility and the room kept temperature from $22{ }^{\circ} \mathrm{C}$ to $24{ }^{\circ} \mathrm{C}$.

Parents were asked (always at beginning and at the end of each module) to respond about functional improvement of the child on daily activities and mobility by their observation to verify some ICF domains of participation in others activities not included on GMFM-88 [20]. Parents should answer the questions: "Did you note any difference in your son's during daily activities? What kind of difference? In which activity?".

\section{Intervention description}

The child completed three modules of INMT (each module: $2 \mathrm{~h}$ hours a day, 5 days a week, during 4 weeks $=40 \mathrm{~h}$ in total $)$ in 7 months, $\left(1^{\text {st }}\right.$ in May, $2^{\text {nd }}$ in September and $3^{\text {rd }}$ in November, with interspersing periods of maintenance ( 4 weeks $=16 \mathrm{~h}$ in total). Each period of maintenance was composed by 2 hours a day of physical therapy, twice a week (June, July, August and October). "Maintenance" are periods between two modules in which the child had less hours of intervention when compared to INMT protocol.

The INMT protocol includes the PediaSuit ${ }^{T M}$, TheraSuit $^{\text {TM }}$, Bobath and the Conventional kinesiotherapy. The INMT terminology is recently used by Neves et al. [15, 16], which presents a protocol of intensive physical therapy during 2-3 hours a day,
5 days a week, during 4 weeks, with individual goals identified by GMFM-88 and a professional experience evaluation. This workload is established according to the main diagnosis. Normally CP and Down syndrome children often do 3 hours a day and children with neurodegenerative diagnosis perform 2 hours a day. In this case report, considering child age and to avoid fatigue, the protocol used 2 hours a day, with rest breaks and fluids intake.

The INMT protocol was composed of: (a) warm up (massages and/or brushing, stretching); (b) endurance exercise in the AUE called Monkey and/or functional activities; (c) exercises with the suit wear from PediaSuit ${ }^{T m}$ in an AUE called Spider with bungee cords; (d) Respiratory exercises when necessary; (e) Gait training $[15,17]$. The gait training is possible even for children without independent walking, like the child from this report due to the suit wear and bungee cords that could provide support. All therapies were conducted by a physical therapist with experience with this protocol.

All intervention procedures were planned based on task-oriented activities (Table 1) exemplified in Figure 1.

Data analyses were carried out using descriptive statistics to compare pre (initial) and post (final) GMFM-88 scores in five dimensions (A to E), due to lack of reference values of motor skills for children with CdLS.

Table 1 - Goals and intervention procedures on INMT protocol for children with CdLS (Curitiba, Brazil, 2015)

\begin{tabular}{|c|c|}
\hline Intended goals & $\begin{array}{l}\text { Procedural interventions } \\
\text { task-oriented activities }\end{array}$ \\
\hline Sensorial stimulation & $\begin{array}{l}\text { Various textures stimulation: box with rice, sago, play dough, soft } \\
\text { glove, brush, temperature variations. }\end{array}$ \\
\hline To promote stretching of upper and lower extremities & Passive manual stretching; \\
\hline To promote global strengthening with focus in lower limbs & Functional strengthening by postural transfers \\
\hline To promote scapular and pelvic mobilization & \\
\hline To improve static and dynamic balance & $\begin{array}{l}\text { Different exercises with bungee cords, balls, } \\
\text { rolls, balance board in the AUE }\end{array}$ \\
\hline $\begin{array}{l}\text { To improve control trunk } \\
\text { To stimulate postural transfers }\end{array}$ & $\begin{array}{l}\text { Movement facilitation to transfer from sit to } 4 \\
\text { points by different ways and surface }\end{array}$ \\
\hline $\begin{array}{l}\text { To stimulate orthostatism } \\
\text { To favor gait phases and suspend gait training }\end{array}$ & $\begin{array}{l}\text { Mobile AUE for gait training on treadmill with weight support and } \\
\text { speed variation (during: } 15 \text { a } 20 \text { minutes), gait facilitation by } \\
\text { physiotherapist. }\end{array}$ \\
\hline
\end{tabular}




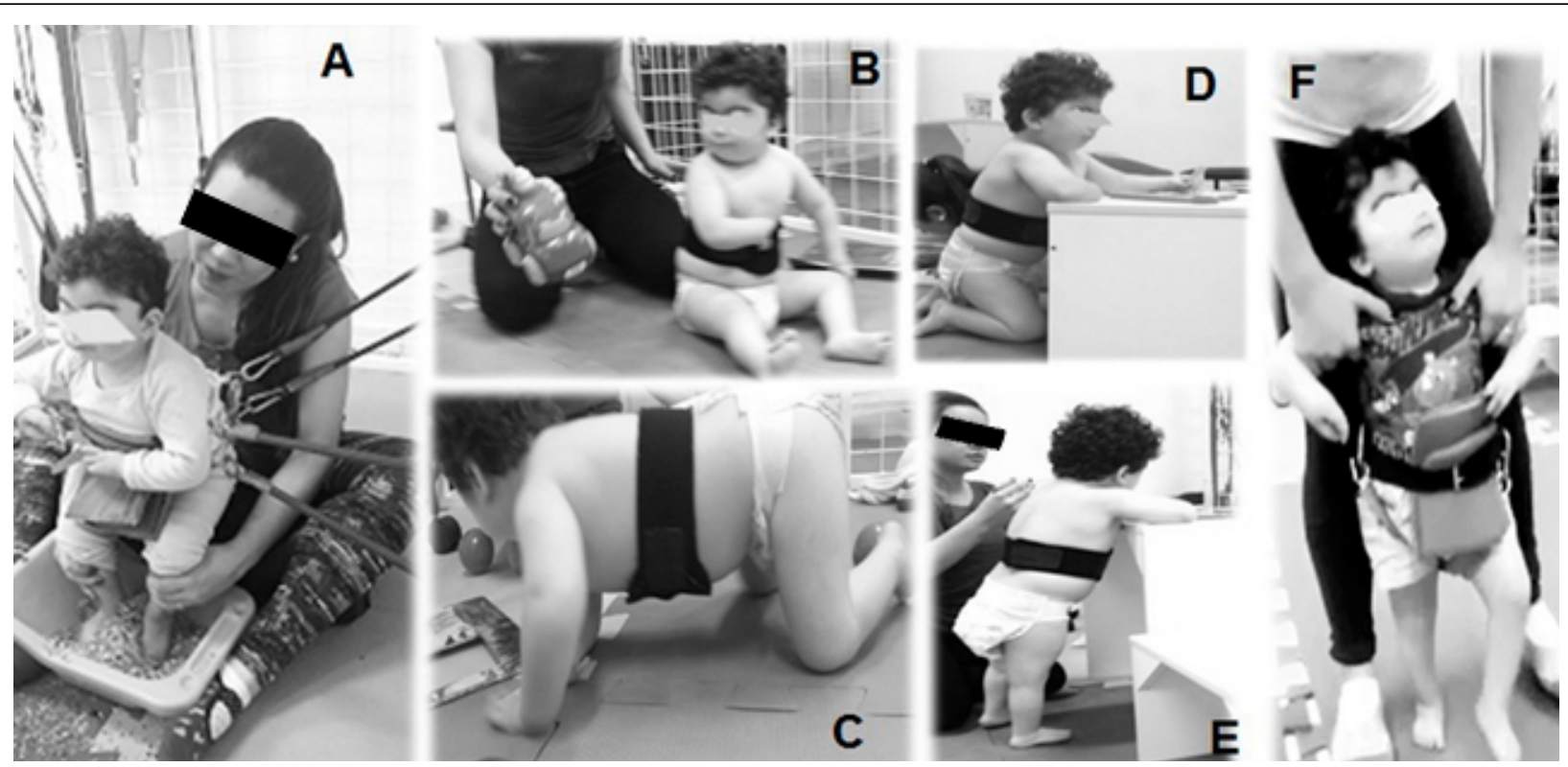

Note: A: Activities of sensorial stimulation; B: incentive to sit and transfer; C: 4 points training and crawling; D: kneeling to stand training; E: stand position; F: gait training.

Figure 1 - Examples of activities during the Intensive Neuromotor Therapy (INMT - Curitiba, Brazil, 2015).

\section{Results}

At the end of INMT, the child was with 2 years and 7 months, $12.8 \mathrm{~kg}$ and $81 \mathrm{~cm}$. The initial and final data evaluation was presented in Table 2. Results show an evolution of the gross motor function with gains of $11.28 \%$ in the $1^{\text {st }}$ module, $9.22 \%$ in the $2^{\text {nd }}$ module, and $10.29 \%$ in the $3^{\text {rd }}$ module.

Table 2 - Initial and final GMFM-88 evaluation from a child with CdLS (Curitiba, Brazil, 2015)

\begin{tabular}{|c|c|c|c|c|c|c|c|c|}
\hline & Moment & $\begin{array}{c}\text { A } \\
\text { (lying and } \\
\text { rolling) }\end{array}$ & $\begin{array}{c}\text { B } \\
\text { (sitting) }\end{array}$ & $\begin{array}{c}\text { C } \\
\text { (crawling and } \\
\text { kneeling) }\end{array}$ & $\begin{array}{c}\text { D } \\
\text { (standing) }\end{array}$ & $\begin{array}{c}\text { E } \\
\text { (walking, } \\
\text { running and } \\
\text { jumping) }\end{array}$ & Total GMFM-88 & Goal areas \\
\hline \multirow{3}{*}{$\stackrel{\overrightarrow{0}}{\sum}$} & M1 Initial & $50.98 \%$ & $26.67 \%$ & $0.00 \%$ & $0.00 \%$ & $0.00 \%$ & $15.53 \%$ & $38.82 \%$ \\
\hline & M1 Final & $82.35 \%$ & $48.33 \%$ & $2.38 \%$ & $0.00 \%$ & $0.00 \%$ & $26.61 \%$ & $44.35 \%$ \\
\hline & M1 Difference & $31.37 \%$ & $21.66 \%$ & $2.38 \%$ & $0.00 \%$ & $0.00 \%$ & $11.28 \%$ & $18.47 \%$ \\
\hline \multirow{3}{*}{ 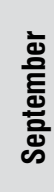 } & M1 Initial & $86.27 \%$ & $33.33 \%$ & $28.57 \%$ & $0.00 \%$ & $0.00 \%$ & $29.64 \%$ & $49.39 \%$ \\
\hline & M1 Final & $98.04 \%$ & $51.67 \%$ & $38.10 \%$ & $5.13 \%$ & $1.39 \%$ & $38.86 \%$ & $38.86 \%$ \\
\hline & M1 Difference & $11.77 \%$ & $18.34 \%$ & $9.53 \%$ & $5.13 \%$ & $1.39 \%$ & $9.22 \%$ & $9.23 \%$ \\
\hline \multirow{4}{*}{$\begin{array}{l}\text { के } \\
\text { हूँ } \\
\text { 흘 }\end{array}$} & M1 Initial & $90.20 \%$ & $43.33 \%$ & $21.43 \%$ & $2.56 \%$ & $0.00 \%$ & $31.50 \%$ & $39.38 \%$ \\
\hline & M1 Final & $98.04 \%$ & $58.33 \%$ & $50.00 \%$ & $2.56 \%$ & $0.00 \%$ & $41.79 \%$ & $52.23 \%$ \\
\hline & M1 Difference & $7.84 \%$ & $15.00 \%$ & $28.57 \%$ & $0.00 \%$ & $0.00 \%$ & $10.29 \%$ & $12.85 \%$ \\
\hline & $\begin{array}{c}\text { Total Difference } \\
\text { (M3Final- } \\
\text { M1Initial) }\end{array}$ & $47.06 \%$ & $31.66 \%$ & $50.00 \%$ & $2.56 \%$ & $0.00 \%$ & $26.26 \%$ & $13.41 \%$ \\
\hline
\end{tabular}

Note: $\mathrm{M}=$ module. 
Table 2 shows a total gain (after three modules of INMT) of $47.06 \%$ in the dimension A (lying and rolling) and $50 \%$ in dimension $\mathrm{C}$ (crawling and kneeling). It is also evident that the gains occurred progressively module-by-module, with higher gains in the $1^{\text {st }}$ module in the dimension A $(31.37 \%)$, in the $2^{\text {nd }}$ module greater gains in dimension B (18.34\%) and $3^{\text {rd }}$ module greater gains in dimension C (28.57\%) which was also the dimension with higher scores in absolute terms, comparing the difference of the three assessed modules.

It can also be observed that the periods between the intensive modules in which the "Maintenance" was carried out for the beginning of a new module demonstrate a drop of punctuation especially in the dimension B and C. This happened both from the $1^{\text {st }}$ to the $2^{\text {nd }}$ module in which the "Maintenance" period was 3 months, and from the $2^{\text {nd }}$ to the $3^{\text {th }}$ in which the interval for a new module was only 1 month.

Since the end of first module, the mother reported the improvement in performance of keeping postures (for mobility domain of ICF). This information was reported again, always at the end of the INMT modules. Initially the mother reported that the patient remained most of the time lying, even to play, but after three INMT modules, he has adopted the sitting posture for longer periods, which facilitate the environment exploration and the use of arms. Therefore, the INMT can be considered a good tool for motor skills gains because it has made the child play at home with better motor function.

During the seven months of intervention, the patient showed improvements in components of the ICF, motor function, noted by the scores of GMFM, and participation in daily activities cited by the mother's report (Figure 2).

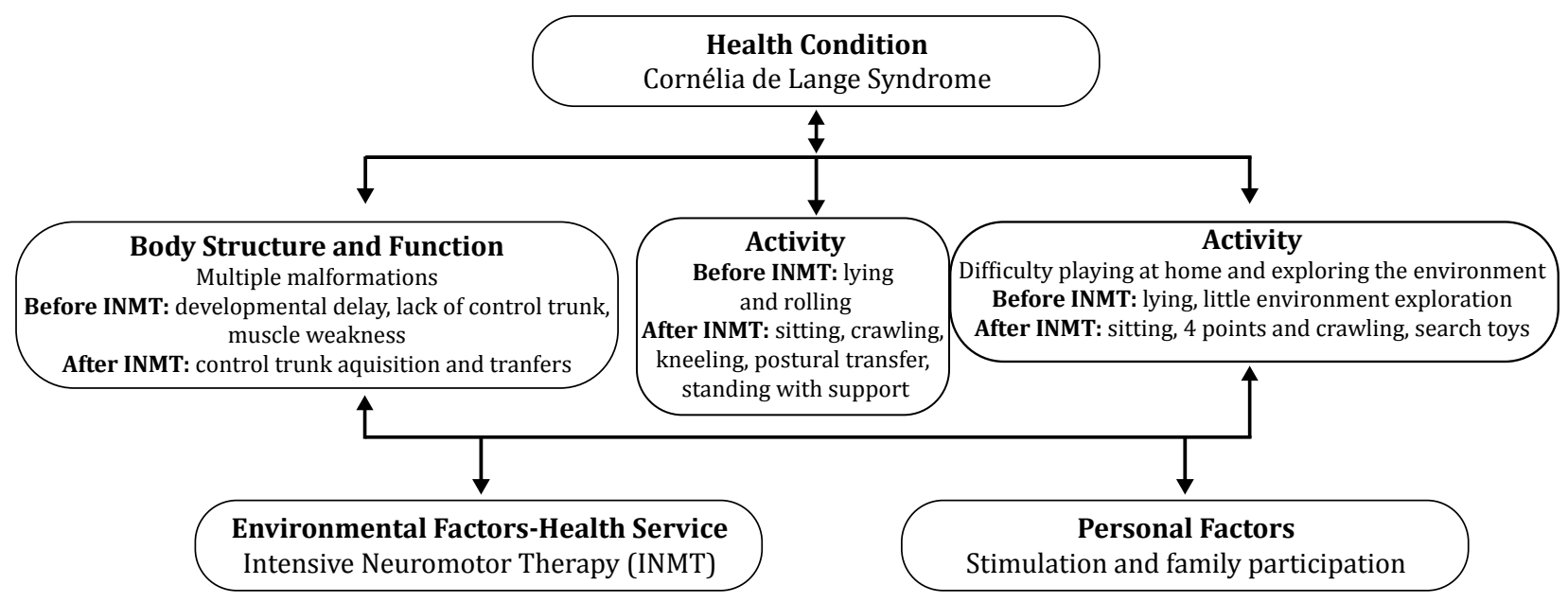

Figure 2 - Principal results of Intensive Neuromotor Therapy (INMT) by ICF model.

\section{Discussion}

Considering CdLS as a rare syndrome and poorly described in terms of possibilities of intervention, physical therapy is an option for a child with neuromotor disorders caused by this syndrome [9]. The literature suggests that high-intensity exercises, as proposed by INMT, with an approach that emphasizes task-oriented activities, with specific goals, are the best way to provide a better learning experience in therapy for daily activities $[21,22]$ confirmed by the results of this case report.
The patient presented larger quantitative gains, in the total score, after the $1^{\text {st }}$ module $(18.47 \%)$. However, when analyzing in terms of complexity of the tasks, it was observed that the gain in the $1^{\text {st }}$ module is mostly related to the supine position (dimension A: $31.37 \%$ ). Probably this gain was the basis for the gains observed in the seated position (dimension B: $18.34 \%$ ) in the $2^{\text {nd }}$ module and to crawling and kneeling (dimension C: $28.57 \%$ ) in the $3^{\text {rd }}$ module.

The child had difficulty in trunk control at the beginning of INMT, which was an intended goal of 
the intervention, especially in antigravity postures. Thus, the acquisition of sitting position (dimension B) represents the first step towards gains in antigravity postures [23]. This gain in control trunk has already been described by authors $[15,16]$ in children with cerebral palsy (CP) and spinal amyotrophy (SA), respectively. Although in this study no scale of fine motor skills or motor functions related to hands were used. However, considering patient hands malformations due to CdLS, it is possible to suggest that the patient gained manual skills because the sitting postural maintenance is strongly associated with an increase of manual skills [24].

The largest gains observed in the dimension $\mathrm{C}$ at the end of the $3^{\text {rd }}$ module related to crawling and kneeling skills show that intervention favored trunk control as well as it allowed to get this posture starting from the sitting posture. This could be explained by the use of the cage ("Monkey" or "Spider") with bungee cords promoting trunk stabilization, with consequent simplification of movements. At the same time, it stimulates the sensory afferents, which would act to stimulate neural connections and allow a better match of tone, body symmetry, would favor the acquisition of motor milestones, improve balance, muscle strength and motor coordination [14]. In addition, dimension $C$ is the key to the acquisition of active environmental exploration [23].

For a long time the sitting posture and crawling were considered distinct marks. Currently there is evidence [23] that these two important marks are closely related, allowing greater exploitation of the environment therefore stimulating development, just as the transition of these positions offers the child experience of change to new skill gains [23]. It was observed a tendency to significant gains in these two functional marks progressively in this study, and probably the intensive training, with variability of stimulus offered in support of a common goal seems to promote the motor functions acquisition. Stimulus variability has been described as the key for development and allows acquisitions and motor skills transfer [25]. For the purpose of trunk control, for example, different positions were planned in the cage in a playful manner, and the patient was encouraged in complex functional tasks, such as walking on treadmill, in supported and facilitated manner.

The exercise of walking on treadmill was another factor that may have spurred gains in the dimensions $\mathrm{C}$ (crawling and kneeling), considering the opportunity to practice the triple flexion patterns, in suspension on treadmill, with verbal stimulus from the physical therapists, reaching complex movements [26] and providing transfer of learning from therapy to the daily activities of the child [21].

Although positive effects of walking on treadmill with partial body weight support seems to be beneficial for children with Down syndrome [27] we did not find articles addressing it in CdLS. It is known that crawling has dissociated complex patterns of motion, requiring balancing the body in alternating movements, which may have been favored with gait training in suspension. It is also known that possibly the crawling acquisition influence on the gait acquisition [28]. In this case, as the gait is still not possible as an independent ability, the training of this activity in suspension may have influenced positively the gains of the less complex motor functions.

The higher quantitative gains observed in this case report in relation to patients with $\mathrm{CP}$ from other studies [29] may be due to the clinical nature of the pathology and its neuromotor changes. Although CdLS present several phenotypic changes [9] which influence directly in the motor development, this syndrome can present tone changes as hypertony found in the facial region of our patient, without changes in trunk and limbs. Thus, when we make a parallel with children with $\mathrm{CP}$ it is possible to note greater gains in those who had less impairments (GMFCS I and II; gains of 4.5\%) [30] and less tone alteration.

An important detail of the INMT protocol is the existence of maintenance periods, in which the child continues to receive an intervention with a lower workload when compared with a module, in order to maintain motor skills acquired in the modules and promote a recovery. These maintenance periods for this case of CdLS show some drop in scores that could reflect the non-retention and/or learning of some skills, which could indicate the need for daily intervention with less workload or indicate cognitive aspects influencing the acquisition of motor skills assessed, since this syndrome affects this aspect. Longitudinal evaluation, even during periods without intervention, is suggested for a better understanding of the evolution of similar cases.

Other important information regarding INMT for children with CdLS refers to the transfer of motor functions gains from the physical therapy activities 
for daily activities, reported by the child's mother. Transfers of intensive training for daily activities had also been reported in children with CP [30]. Thus, according to an ecological vision, the INMT improved the gross motor function of the patient with CdLS, when assessed by GMFM-88 and it facilitated his participation in some daily activities according to ICF domains (evaluated by parents).

One limitation of the study was the non-blinding of the evaluator.

Although INMT resulted in improvements in gross motor function and participation during daily activities in a child with CDLS, more studies are needed to bring scientific evidence of the effect of physical therapy (INMT) in children with CdLS, with a larger sample and comparison with other forms of intervention.

\section{References}

1. Broitman, DH, Heredia, JF, Campo, MD. Síndrome Cornelia de Langue. Rev Chil Pediatr. 1980;51(1):55-8.

2. Nelson L, Moss J, Oliver C. A longitudinal follow-up study of affect in children and adults with Cornelia de Lange syndrome. Am J Intellect Dev Disabil. 2014;119(3):235-52.

3. Grau Carbó J, López Jiménez J, Giménez Prats M, Sànchez Molins M. Cornelia de Lange syndrome: a case report. Med Oral Patol Oral Cir Bucal. 2007;12(6):E445-8.

4. Deardorff MA, Noon SE, Krantz ID. Cornelia de Lange syndrome. GeneReviews2016. Available from: https://www.ncbi.nlm.nih.gov/books/NBK1104/.

5. Olioso G, Passarini A, Atzeri F, Milani D, Cereda A, Cerutti $\mathrm{M}$, et al. Clinical problems and everyday abilities of a group of Italian adolescent and young adults with Cornelia de Lange syndrome. Am J Med Genet Part A. 2009;149A:2532-7.

6. Sztajnberg M, Pompeu F, Teixeira I, Carneiro S, Schulz I, Ribeiro S. Brachmann-de Lange syndrome: report of three cases. Arq neuropsiquiatr. 1973;31(2):96-104.

7. Oliver C, Arron K, Sloneem J, Hall S. Behavioural phenotype of Cornelia de Lange syndrome: casecontrol study. Br J Psychiatry. 2008;193(6):466-70.
8. Castilho-Weinert LV, Forti-Bellani CD. Fisioterapia em Neuropediatria. Curitiba: Omnipax; 2011.

9. Mikołajewska E. Interdisciplinary therapy in Cornelia de Lange syndrome: review of the literature. Adv Clin Exp Med. 2013;22(4):571-7.

10. January K, Conway LJ, Deardorff M, Harrington A, Krantz ID, Loomes $\mathrm{K}$, et al., editors. Benefits and limitations of a multidisciplinary approach to individualized management of Cornelia de Lange syndrome and related diagnoses. Am J Med Genet C Semin Med Genet. 2016;172(2):237-45.

11. Dornelas LF, Lambertucci MS, Lima Mello M, Deloroso FT. Aplicabilidade da Classificação Internacional de Funcionalidade, Incapacidade e Saúde (CIF) para a avaliação de crianças com paralisia cerebral: uma revisão sistemática. Cad Ter Ocup UFSCar. 2014;22(3):579-90.

12. Gannotti ME, Christy JB, Heathcock JC, Kolobe TH. A path model for evaluating dosing parameters for children with cerebral palsy. Phys Ther. 2014;94(3):411-21.

13. Mélo TR. Escalas de avaliação do desenvolvimento e habilidades motoras: AIMS, PEDI, GMFM e GMFCS. In: Castilho-Weinert L, Forti-Bellani C, editors. Fisioterapia em Neurologia. Curitiba: Omnipax; 2011. p. 23-42.

14. Mélo TR, Yamaguchi B, Chiarello CR, Costin ACS, Erthal $\mathrm{V}$, Israel VL, et al. Intensive neuromotor therapy with suit improves motor gross function in cerebral palsy: a Brazilian study. Motricidade. 2017;13(4):54-61.

15. Neves EB, Krueger E, Stéphani de Pol MC, Oliveira N, Szinke AF, Oliveira Rosário M. Benefícios da Terapia Neuromotora Intensiva (TNMI) para o controle do tronco de crianças com paralisia cerebral. Rev Neurocienc. 2013;21:549-55.

16. Neves EB, Krueger E, Santos Cióla MC, Costin ACMS, Chiarello CR, Oliveira Rosário M. Terapia Neuromotora Intensiva na reabilitação da atrofia muscular espinhal: estudo de caso. Rev Neurocienc. 2014;22(1):66-74.

17. Scheeren EM, Mascarenhas LPG, Chiarello CR, Costin ACMS, Oliveira L, Neves EB. Description of Pediasuit Protocol $^{\mathrm{TM}}$. Fisioter Mov. 2012;25(3):473-80. 
18. Lima JL, Mélo TR, Costin ACS, Neves EB. Terapia neuromotora intensiva nas habilidades motoras de criança com Síndrome de Down. Rev Bras Pesqui Saúde. 2018;19(2):133-9.

19. Barreto IA, Chiarello CR, Erthal V, Mélo TR. Terapia Neuromotora Intensiva favorece manutenção do controle de cabeça e tronco em crianças com amiotrofia espinhal: série de casos. Rev Uniandrade. 2016;17(3):139-48.

20. Organização Mundial de Saúde. CIF: classificação internacional de funcionalidade, incapacidade e saúde. São Paulo: Edusp; 2015.

21. Bower E, McLellan D, Amey J, Campbell MJ. A randomised controlled trial of different intensities of physiotherapy and different goal setting procedures in 44 children with cerebral palsy. Dev Med Child Neurol. 1996;38(3):226-37.

22. Størvold GV, Jahnsen R. Intensive motor skills training program combining group and individual sessions for children with cerebral palsy. Pediatr Phys Ther. 2010;22(2):150-9.

23. Soska KC, Robinson SR, Adolph KE. A new twist on old ideas: how sitting reorients crawlers. Dev Sci. 2015;18(2):206-18.

24. Rachwani J, Santamaria V, Saavedra SL, Woollacott $\mathrm{MH}$. The development of trunk control and its relation to reaching in infancy: a longitudinal study. Front Hum Neurosci. 2015;9:94.

25. Dusing SC, Harbourne RT. Variability in postural control during infancy: implications for development, assessment, and intervention. Phys Ther. 2010;90(12):1838-49.
26. Damiano DL. Activity, activity, activity: rethinking our physical therapy approach to cerebral palsy. Phys Ther. 2006;86(11):1534-40.

27. Damiano DL, DeJong SL. A systematic review of the effectiveness of treadmill training and body weight support in pediatric rehabilitation. J Neurol Phys Ther. 2009;33(1):27-44.

28. Righetti L, Nylén A, Rosander K, Ijspeert AJ. Kinematic and gait similarities between crawling human infants and other quadruped mammals. Front Neurol. 2015;6:17.

29. Bailes AF, Greve K, Burch CK, Reder R, Lin L, Huth MM. The effect of suit wear during an intensive therapy program in children with cerebral palsy. Pediatric Phys Ther. 2011;23(2):136-42.

30. Sorsdahl AB, Moe-Nilssen R, Kaale HK, Rieber J, Strand LI. Change in basic motor abilities, quality of movement and everyday activities following intensive, goal-directed, activity-focused physiotherapy in a group setting for children with cerebral palsy. BMC Pediatr. 2010;10:26.
Received in 10/08/2018

Recebido em 08/10/2018

Recibido en 08/10/2018

Approved in 07/22/2019

Aprovado em 22/07/2019

Aprobado en 22/07/2019 